\title{
Association between bovine leukemia virus proviral load and severity of clinical mastitis
}

\author{
Aiko WATANABE ${ }^{1,2)}$, Hironobu MURAKAMI ${ }^{1)}$, Seiichi KAKINUMA ${ }^{2)}$, \\ Koki MURAO' ${ }^{2)}$, Kaori OHMAE ${ }^{2}$, Naoki ISOBE ${ }^{3)}$, Hirohisa AKAMATSU4), \\ Takahiro SETO ${ }^{5)}$, Shinji HASHIMURA ${ }^{6)}$, Kunitoshi KONDA6), \\ Yasunori SHINOZUKA ${ }^{1)}$ and Kazuhiro KAWAI ${ }^{1) *}$ \\ ${ }^{1)}$ School of Veterinary Medicine, Azabu University, 1-17-71, Fuchinobe, Chuo-ku, Sagamihara, \\ Kanagawa 252-5201, Japan \\ ${ }^{2)}$ Kakinuma Veterinary Hospital, Honjo, 200-1, Kodama, Kodama-cho, Honjo, Saitama 367-0212, Japan \\ ${ }^{3)}$ Graduate School of Biosphere Science, Hiroshima University, Higashi-Hiroshima, Hiroshima 739-8528, Japan \\ ${ }^{4)}$ Akamatsu Farm Clinic, 857-11, Miyahara, Fujinomiya, Shizuoka 418-0005, Japan \\ ${ }^{5)}$ Shizuoka Prefecture Livestock Research Institute, 1945, Inokashira, Fujinomiya, Shizuoka 418-0108, Japan \\ ${ }^{6)}$ Kanagawa Prefectural Livestock Industry Technology Center, 3750, Hongo, Ebina, Kanagawa 243-0417, Japan
}

J. Vet. Med. Sci.

81(10): 1431-1437, 2019

doi: 10.1292/jvms.19-0285

Received: 27 May 2019

Accepted: 29 July 2019

Advanced Epub:

12 August 2019
ABSTRACT. The purpose of this study was to clarify the effect of Bovine leukemia virus (BLV) infection on natural immunity in the bovine mammary gland and on the severity of clinical mastitis. We classified milk samples from clinical mastitic cows into BLV-positive $(n=76)$ and BLV-negative $(n=12)$. BLV-positive cows were further divided into cows with High BLV proviral load $(H-P V L)(n=23)$ and Low BLV proviral load (L-PVL) $(n=53)$. Severity of clinical mastitis was classified as MILD, MODERATE, or SEVERE. Multiple logistic regression analysis was performed on the host factors and environmental factors with severity of clinical mastitis as the objective variable. BLV proviral load (PVL) and season at onset of mastitis showed significant correlation with the severity of clinical mastitis. Binary logistic regression analysis was performed on natural immunity factors lactoferrin and lingual antimicrobial peptide (LAP) concentration in milk, with PVL as the objective variable. Of these natural immunity factors, LAP concentration in milk showed significant correlation with PVL. The results of the present study suggested that PVL and season are associated with severity of clinical mastitis, and that the immune function in the mammary gland is decreased in cows with H-PVL compared to that in cows with L-PVL.

KEY WORDS: bovine leukemia virus, clinical mastitis, lingual antimicrobial peptide, proviral load, severity

Bovine leukemia virus (BLV) is the causative agent of enzootic bovine leukosis (EBL), a fatal disease whose occurrence in Japan has been steadily on the rise [33]. Recently, it was reported that BLV-infected cows exhibited decreased milk production even before the onset of EBL symptoms $[13,15]$, and that the recurrence rate and morbidity rate were significantly higher on a farm with a high incidence of BLV-positive cows than on a farm with no BLV-positive cows [27]. The economic losses due to BLV infection are enormous [35].

Upon infection of cows, BLV is integrated into the animal's genome as a provirus, where these sequences remain for the rest of the host's life [38]. BLV infection can be diagnosed by screening (via polymerase chain reaction (PCR)) for the presence of the provirus within the host genome [3,26]. Studies have suggested the use of a BLV proviral load (PVL; i.e., the number of provirus copies) of 1,000 copies per $10 \mathrm{ng}$ DNA (the high viral load, or "H-PVL") as a standard for defining the infectious state and disease in the host [43]. Notably, reports show that $65 \%$ of cows with EBL harbor H-PVL, and that cows with H-PVL have an increased tendency to infect other cows $[26,31,43]$. Furthermore, the inhibitory receptor programmed death-1 (PD-1) expressed on T cells and B cells, which are known as effector cells, and its ligand, programmed death-ligand 1 (PD-L1), have been reported to be closely involved in the viral dynamics of BLV and disease progression [21,22], the reduced action of NK cells [27, 36], and the reduction in neutrophil function $[13,14]$ in BLV-infected cows. These data imply that BLV may influence the severity and infectivity of other pathogen-mediated diseases [16].

At the same time, bovine mastitis, a common infectious disease in the mammary glands of dairy cows, causes considerable economic losses in the dairy industry due to lowered milk production and quality; this disease requires the use of antibiotics for 
treatment, and impedes milk delivery due to increases in somatic cell count (SCC) [6, 11]. Particularly, it is reported that severe mastitis causes significantly reduced milk production and requires complex treatment (using multiple antibiotics) compared to mild mastitis [37]. The causes of mastitis vary widely [11]; consistently, however, infection of the mammary gland results in the rapid accumulation of neutrophils, lactoferrin (LF), $\beta$-lactoglobulin, and defensin, all of which have been reported to be significant host factors for the disease $[45,46]$. The cells that contribute to the SCC include neutrophils that enter the mammary gland in response to mammary infection and mammary gland epithelial cells that are shed into the milk. As a result, the SCC serves as an important indicator of the inflammatory response due to intramammary infection [7, 42]. Recently, it has been reported that the lingual antimicrobial peptide (LAP), a member of the $\beta$-defensin family of peptides, is secreted from mammary epithelial cells into the milk $[19,23]$, and it is known that LAP in milk exhibits nonspecific activity against many kinds of bacteria and viruses, potentially resulting in bacteriolysis [24]. Similarly, LF, an iron-binding glycoprotein, is known to inhibit bacterial growth [2, 12]; LF is synthesized by mammary epithelial cells and neutrophils before being secreted into the milk [4,20]. Recently, increases in parity have been reported to correlate with decreases, in milk, of LF concentrations [17] and lactoperoxidase (LPO) activity [25]. Thus, host factors appear to play a large role in innate immunity.

There have been several reports on the relationship between BLV infection and clinical mastitis, including reports that the incidence of subclinical mastitis is higher in cows with persistent lymphocytosis (PL) [41], and that the SCC is elevated in cows with EBL, presumably reflecting the immunosuppressive effect of BLV infection [10, 40]. Economic loss due to changes in milk production from BLV infection is being brought to attention. Therefore, investigation of the economic losses associated with both mastitis and BLV infection is essential in better understanding the impact of infectious disease on the dairy industry economy. However, the effect of BLV infection on the severity of clinical mastitis during lactation, including the relationship between PVL and the severity of clinical mastitis, has not (to our knowledge) previously been reported.

Thus, the purpose of the present study was to clarify the effect of BLV infection on natural immunity in the bovine mammary gland and on the severity of clinical mastitis.

\section{MATERIALS AND METHODS}

\section{Cows}

Milk samples were collected from a total of 88 quarters from 88 lactating Holstein-Friesian dairy cows with clinical mastitis. The cows were located on 2 farms in Saitama Prefecture. Sampling was performed from March 2016 to April 2017. Mastitic cows were identified by clinical evaluation and diagnosis by a veterinarian. On the day of onset of mastitis, milk samples were collected aseptically from each cow, and peripheral blood was collected from the tail vein using EDTA-2Na-containing vacuum blood collection tubes. The collected milk was assessed by bacterial culture test and SCC was measured before storage of the milk at $-80^{\circ} \mathrm{C}$ pending measurement of LF and LAP concentrations. Blood was used for BLV detection tests, which were performed by quantitative PCR.

\section{Severity of clinical mastitis}

The severity of clinical mastitis was defined according to the existing classification method $[5,8,39]$. In short, the severity at the onset of clinical mastitis was classified as MILD (those with milk abnormalities such as clots in milk, significant milk reduction, high SCC, and discoloration), MODERATE (those with milk abnormalities and udder abnormalities such as swelling and hardness), or SEVERE (those with milk abnormalities, udder abnormalities and general symptoms such as fever, general depression and anorexia). For cows with clinical mastitis in multiple quarters, the quarter with the highest detected bacterial count was selected.

\section{Bacterial culture from milk}

Milk samples were cultured on 5\% sheep blood agar, and the bacteria present in milk samples were identified according to the procedure described by the National Mastitis Council [18].

\section{Measurement of SCC in milk}

SCC was performed as previously described [29]. Specifically, milk was diluted 10-fold with sterile saline $(100 \mu l$ of milk +900 $\mu l$ of saline) and cells were quantified using a DeLaval cell counter (DeLaval International AB, Tumba, Sweden).

\section{Measurement of LF concentration in milk}

The LF in milk was measured using a single radial immunodiffusion kit (MCC: Mitsumaru Chemical Co., Ltd., Shibata-gun, Japan).

\section{Measurement of LAP concentration in milk}

Milk fat was removed by centrifugation at $1,700 \times \mathrm{g}$ for $30 \mathrm{~min}$ at $4^{\circ} \mathrm{C}$. The concentration of LAP in skim milk was measured as previously described [23]. Briefly, a 96-well microtiter plate was coated with $2 \mu \mathrm{g} / \mathrm{m} l$ anti-LAP antibody in carbonate buffer ( $\mathrm{pH}$ 9.7) at $4{ }^{\circ} \mathrm{C}$ overnight; this step was followed by blocking with $0.05 \mathrm{M}$ borate buffer supplemented with $0.2 \%$ bovine serum albumin at $\mathrm{pH}$ 7.8. Skim milk samples were diluted 10 -fold with borate buffer. Equal volumes ( $0.05 \mathrm{~m} l$ each) of the 10 -fold diluted skim milk and horseradish peroxidase-labeled LAP [23] were pipetted into wells followed by incubation for $3 \mathrm{hr}$ at room 
temperature. After washing four times with phosphate-buffered saline, the wells were incubated with $0.15 \mathrm{~m} l$ of tetramethyl benzidine solution for $30 \mathrm{~min}$. The optical density was measured at a wavelength of $655 \mathrm{~nm}$ using Multiskan FC (Thermo Fisher Scientific, Tokyo, Japan). Assays were performed in duplicate. The sensitivity and recovery of LAP were 0.04 nM and 100-115\%, respectively. The coefficients of variation for intra- and interassay variation were 6.5 and $13.5 \%$, respectively.

\section{Quantitative PCR ( $q P C R)$ for BLV}

As described previously [32], qPCR to quantify viral and proviral BLV genome levels was performed for all samples using the 7500 Real-Time PCR system (Applied Biosystems, Foster City, CA, U.S.A.). The primers 5'-GGACAAATGGACTGCTCAAAC-3' and 5'-CTCCCATCTGGTCTTTAGAATTG-3' and the probe 5'-FAM-CTTCCCATGACTCAGGCCCTTTCT-TAM-3' were used to measure proviral load in BLV cattle and viral copy number in the supernatant of clone-transfected HeLa cells. The primer and probe used in this study were designed to target the highly conserved gene region encoding BLV polymerase (The GenBank accession numbers are LC164083, LC164084, LC164085, and LC164086). A standard curve was generated using serial dilutions of pBLV-FLK as the template, and the viral copy number was calculated.

\section{Diagnosis and classification of BLV status}

If a PVL was detected by PCR, the sample was defined as BLV positive; if PVL was not detected by PCR, the sample was defined as BLV negative [47]. Among the BLV-positive cows, animals harboring a PVL of $\geq 1,000$ copies / 10 ng DNA were classified as H-PVL cows; animals harboring a PVL of $<1,000$ copies / $10 \mathrm{ng}$ DNA were classified as L-PVL cows.

\section{Statistical analysis}

Fisher's exact test was used to compare pathogens between BLV positive and negative groups. The host factors (age, days in milk, teat-end score, PVL, and concurrent disease) and environmental factors (farm and season at onset of mastitis) were individually analyzed by univariate analysis to identify the factors that had effects on the severity of clinical mastitis. The KruskalWallis test was used to analyze numerical values (age, days in milk) and the Fisher's exact test was used to analyze nominal values (PVL, concurrent disease, farm, and season at onset of mastitis). Variables with $P<0.2$ in the univariate analysis were selected as explanatory variables, severity of clinical mastitis was selected as the objective variable, and multiple logistic regression analysis was performed.

To investigate the relationship between PVL and natural immunity factors at the onset of mastitis, the Wilcoxon rank-sum test was used for univariate analysis to analyze PVL against SCC in milk, LAP concentration in milk, and LF concentration in milk. Variables with $P<0.2$ were selected as explanatory factors, PVL was selected as the objective variable, and binary logistic regression analysis was performed by the "forced entry" method. A probability of $P<0.05$ was considered significant. IBM SPSS Statistics 22.0 software (International Business Machines Co., Ltd., New York, NY, U.S.A.) was used for all statistical analysis.

\section{RESULTS}

Summary and comparison of severity of clinical mastitis between BLV-positive cows and BLV-negative cows at first onset Out of the 88 cows used for this experiment, the PCR method detected PVL at the onset of clinical mastitis in 76 quarters from 76 cows; therefore, these animals were defined as BLV-positive cows. No PVL was detected in 12 quarters from 12 cows; therefore, these animals were defined as BLV-negative cows. Additionally, Streptococci (31/88), Coagulase-negative-staphylococci (14/88), Staphylococcus aureus (14/88), Coliform (4/88), Corynebacterium bovis (3/88), Yeast (1/88), Prototheca zopfii (1/88) were isolated from 88 milk samples; however, no significant difference was found in the detection rate of pathogens between BLVpositive and BLV-negative cows (data not shown). 18 samples were no growth and 2 samples were contamination.

\section{Host factors associated with severity of clinical mastitis}

Univariate analysis of individual factors and severity of clinical mastitis (Table 1) identified four factors (days in milk, PVL, farm, and season at onset of mastitis) for inclusion in the multiple logistic regression analysis. Of those factors, PVL $(P=0.0029$, odds ratio $=5.396$ ) and season at onset of mastitis (spring: $P=0.0011$, odds ratio $=28.167$; summer: $P=0.009$, odds ratio $=81.732$; autumn: $P=0.024$, odds ratio=23.383) showed significant correlation with the severity of clinical mastitis (Table 2).

\section{Relationship of PVL to natural immunity factors in milk at onset of mastitis}

Within the BLV-positive group, 23 quarters were H-PVL and 53 quarters were L-PVL. Univariate analysis of each factor and PVL (Table 3) identified two factors (LF concentration, and LAP concentration in milk) for inclusion in the binary logistic regression analysis (Table 4). Of these natural immunity factors, LAP concentration in milk showed significant correlation with PVL $(P=0.023$, odds ratio $=0.89)$.

\section{DISCUSSION}

Results from our multiple regression analysis suggested that PVL and season at onset of mastitis are strongly correlated with the severity of clinical mastitis. The results showed that development of severe clinical mastitis was observed 23.383 times more frequently in spring, 81.732 times more frequently in summer, and 23.383 times more frequently in autumn compared with cases 
Table 1. Univariate analysis of host factors for clinical severity of mastitis at onset

\begin{tabular}{|c|c|c|c|c|c|}
\hline \multirow{2}{*}{ Variables } & \multirow{2}{*}{ Category } & \multicolumn{3}{|c|}{ Severity } & \multirow{2}{*}{$P$ value } \\
\hline & & Mild $(n=25)$ & Moderate $(n=44)$ & Severe $(n=19)$ & \\
\hline \multicolumn{6}{|l|}{ Numerical } \\
\hline Age (year) & & $4.6 \pm 1.5$ & $4.4 \pm 1.5$ & $4.2 \pm 1.8$ & 0.504 \\
\hline Days in milk & & $177.5 \pm 97.7$ & $175.55 \pm 141.9$ & $101.9 \pm 79.4$ & $0.091^{\mathrm{a})}$ \\
\hline \multicolumn{6}{|l|}{ Categorical } \\
\hline \multirow[t]{3}{*}{ Proviral load } & $1,000 \leq$ & 6 & 7 & 10 & \\
\hline & $<1,000$ & 15 & 29 & 9 & $0.027^{\mathrm{a})}$ \\
\hline & 0 & 4 & 8 & 0 & \\
\hline \multirow[t]{2}{*}{ Farm } & 1 & 6 & 9 & 11 & $0.011^{\text {a) }}$ \\
\hline & 2 & 19 & 35 & 8 & \\
\hline \multirow[t]{2}{*}{ Concurrent disease } & Yes & 0 & 0 & 1 & \\
\hline & No & 25 & 44 & 18 & 0.216 \\
\hline \multirow[t]{4}{*}{ Season } & Spring & 5 & 12 & 9 & \\
\hline & Summer & 2 & 10 & 4 & \\
\hline & Autumn & 3 & 10 & 5 & $0.08^{\mathrm{a})}$ \\
\hline & Winter & 15 & 12 & 1 & \\
\hline
\end{tabular}

Numerical variables were presented as means \pm SDs and examined by the Kruskal-Wallis test. Categorical variables were presented as numbers and examined by the Fisher's exact test (a: $P<0.2$ ). $\mathrm{SD}=$ standard deviation.

Table 2. Variables associated with clinical severity according to multiple logistic regression analysis

\begin{tabular}{|c|c|c|c|c|c|c|c|c|}
\hline \multirow{2}{*}{$\begin{array}{l}\text { Clinical } \\
\text { severity }\end{array}$} & \multirow{2}{*}{ Variables } & \multirow{2}{*}{$\mathrm{B}$} & \multirow{2}{*}{ SE } & \multirow{2}{*}{ Wald } & \multirow{2}{*}{$P$ value } & \multirow{2}{*}{$\operatorname{Exp}(\mathrm{B})$} & \multicolumn{2}{|c|}{$95 \%$ confidence interval } \\
\hline & & & & & & & Lower & Upper \\
\hline \multirow[t]{8}{*}{2} & Proviral load (PVL) $(1,000 \leq: 2,<1,000: 1,0: 0)$ & -0.163 & 0.528 & 0.096 & 0.757 & 0.849 & 0.302 & 2.392 \\
\hline & Days in milk & 0.001 & 0.003 & 0.043 & 0.836 & 1.001 & 0.995 & 1.006 \\
\hline & {$[$ Farm $=1]$} & -0.086 & 0.694 & 0 & 0.901 & 0.918 & 0.236 & 3.573 \\
\hline & {$[$ Farm=2] } & $0 \mathrm{~b}$ & & & & & & \\
\hline & {$[$ Season $=1]$} & 0.888 & 0.758 & 1.372 & 0.241 & 2.429 & 0.550 & 10.727 \\
\hline & {$[$ Season $=2]$} & 1.941 & 1.180 & 2.707 & 0.100 & 6.963 & 0.690 & 70.278 \\
\hline & {$[$ Season $=3]$} & 0.751 & 0.820 & 0.839 & 0.360 & 2.119 & 0.425 & 10.566 \\
\hline & {$[$ Season $=4]$} & 0 & & & & & & \\
\hline \multirow[t]{8}{*}{3} & $\operatorname{PVL}(1,000 \leq: 2,<1,000: 1,0: 0)$ & 1.686 & 0.774 & 4.744 & $0.029^{\mathrm{a})}$ & 5.396 & 1.184 & 24.597 \\
\hline & Days in milk & -0.004 & 0.004 & 1.434 & 0.231 & 0.996 & 0.988 & 1.003 \\
\hline & {$[$ Farm $=1]$} & 0.735 & 0.859 & 1 & 0.392 & 2.085 & 0.387 & 11.223 \\
\hline & {$[$ Farm $=2]$} & $0 \mathrm{~b}$ & & & & & & \\
\hline & {$[$ Season $=1]$} & 3.338 & 1.320 & 6.395 & $0.011^{\text {a) }}$ & 28.167 & 2.119 & 374.438 \\
\hline & {$[$ Season $=2]$} & 4.403 & 1.694 & 6.757 & $0.009^{\mathrm{a})}$ & 81.732 & 2.954 & $2,261.456$ \\
\hline & {$[$ Season $=3]$} & 3.152 & 1.400 & 5.071 & $0.024^{\mathrm{a})}$ & 23.383 & 1.505 & 363.313 \\
\hline & {$[$ Season $=4]$} & 0 & & & & & & \\
\hline
\end{tabular}

Dependent variable: Clinical severity of mastitis. The reference category is: Clinical severity 1 . SE=standard error. 1,000 means harboring a blood PVL of $\geq 1,000$ copies $/ 10 \mathrm{ng}$ DNA, $<1,000$ means harboring a blood PVL of $<1,000$ copies $/ 10 \mathrm{ng}$ DNA, 0 means Bovine leukemia virus-negative. Season=1 means spring, Season $=2$ means summer, Season $=3$ measn autumn, Season $=4$ means winter. PVL and season are significantly associated with severity of clinical mastitis (a: $P<0.05$ ).

Table 3. Univariate analysis of innate immunity factors for proviral load (PVL)

\begin{tabular}{|c|c|c|c|}
\hline \multirow{2}{*}{ Variables } & \multicolumn{2}{|c|}{ PVL } & \multirow{2}{*}{$P$ value } \\
\hline & Low-PVL $(\mathrm{n}=53)$ & High-PVL $(\mathrm{n}=23)$ & \\
\hline $\mathrm{SCC}$ in milk mean $(\log \mathrm{X} / \mathrm{m} l) \pm \mathrm{SD}$ & $6.77 \pm 0.56$ & $6.99 \pm 0.52$ & 0.893 \\
\hline LAP in milk mean $(n \mathrm{~g} / \mathrm{m} l) \pm \mathrm{SD}$ & $20.3 \pm 11.1$ & $14.1 \pm 3.9$ & $0.04^{\text {a) }}$ \\
\hline LF in milk mean $(\mu \mathrm{g} / \mathrm{m} l) \pm \mathrm{SD}$ & $1,799.8 \pm 1,636.2$ & $1,296.5 \pm 785.3$ & $0.05^{\mathrm{a})}$ \\
\hline
\end{tabular}


Table 4. Variables associated with bovine leukemia virus proviral load (BLV PVL) in peripheral bloods according to binary logistic regression analysis

\begin{tabular}{llllllll}
\hline \multirow{2}{*}{ Variables } & \multirow{2}{*}{$\mathrm{B}$} & \multirow{2}{*}{$\mathrm{SE}$} & Wald & \multirow{2}{*}{$P$ value } & \multirow{2}{*}{$\operatorname{Exp}(\mathrm{B})$} & \multicolumn{2}{c}{$95 \%$ confidence interval } \\
\cline { 5 - 8 } & & & & & & Lower & Upper \\
\hline LAP in milk & -0.122 & 0.054 & 5.167 & $0.023^{\text {a) }}$ & 0.89 & 0.797 & 0.983 \\
LF in milk & 0 & 0 & 1.024 & 0.312 & 1.00 & 0.999 & 1.000 \\
\hline
\end{tabular}

Dependent variable: BLV PVL. SE=standard error, LAP: lingual antimicrobial peptide, LF: lactoferrin. LAP in milk is significantly associated with BLV PVL in peripheral bloods (a: $P<0.05$ ).

of mild clinical mastitis during the respective season. It has been reported that SCC increases in summer [9], suggesting that season at onset of clinical mastitis is associated with severity of clinical mastitis. In addition to season at onset of mastitis, factors such as age, teat-end score, and bacterial presence previously have been reported to be involved in the severity of clinical mastitis [11]. The present report did not reveal a significant role for these specific factors in the severity of clinical mastitis; however, with development of severe clinical mastitis, PVL was observed 5.396 times more frequently compared to development of mild clinical mastitis. This observation suggested that there is a relationship between severity of clinical mastitis and BLV infection. Other studies have reported that BLV-infected cows with PL have high PVLs [1, 43] and increased incidence of mastitis [41]. Our results suggested that PVL is significantly associated with the severity of clinical mastitis. We presume that cows with PL were categorized in the H-PVL group in our study. Given that animals with more-severe clinical mastitis may exhibit delayed recovery, it may be necessary to reassess the methods and compounds used for treatment of these cows.

The effect of BLV infection on innate immunity of the mammary gland remains poorly characterized. It has been reported that the progression of severity in clinical mastitis is largely dependent on innate immune function at the onset of mastitis [44]; therefore, we expected that blood BLV PVL and innate immunity in the mammary gland would show correlation. Our results showed that there is a relationship between PVL and LAP in milk. It is known that LAP in milk attacks many kinds of bacteria or viruses nonspecifically, and can be a cause of bacteriolysis [24]. It has been reported that type-17 T helper (Th17) cells, which are a subset of $\mathrm{CD}^{+}$effector T cells, secrete antimicrobial peptides when in proximity to epithelial cells; Th17 cells also have been shown to induce proliferation and mobilization of neutrophils, and to proliferate with progression of disease in the mammary gland of mice with mastitis [34, 48]. In BLV-positive cows, the expression of PD-1 and PD-L1 is enhanced and immune exhaustion of effector cells has been observed [21,22]. Therefore, we hypothesize that LAP expression in mammary epithelium may have been suppressed in H-PVL cows. Our results did not show any relationship between PVL and SCC in milk. There remains the possibility that SCC in milk in both H-PVL and L-PVL cows may have shown to be even higher without BLV infection, and it is difficult to determine the actual degree of decrease of SCC in milk in both H-PVL and L-PVL cows. Our results did not show any relationship between PVL and LF in milk. It has been reported that LF concentration in milk after development of clinical mastitis becomes lower with occurrence of severe mastitis at onset [28], and that comparatively with LAP concentration in milk increasing immediately after onset, LF in milk increases $12 \mathrm{hr}$ after occurrence of clinical mastitis [19, 30]. In this study, we used milk samples collected immediately after occurrence, which suggested the possibility that results reflect values before LF in milk had increased.

The results of the present study suggested that PVL and season are associated with severity of clinical mastitis, and that the immune function of epithelial cells in the mammary gland is decreased in cows with H-PVL compared to that in cows with L-PVL. Recent evidence indicates the value of identifying BLV-positive cows based on the level of the PVL [31, 43]. We believe that the results of our study further support the importance of tracking BLV-positive cows with H-PVL within the herd. At onset of mastitis, we believe there is a need to treat clinical mastitis taking into account the likely decreases in immune system function in the mammary glands of BLV-positive cows. However, it appears that not only PVL but also season at onset of clinical mastitis is strongly associated with severity of clinical mastitis, suggesting that it is necessary to consider not only BLV infection, but also factors other than BLV infection, in investigating the severity of clinical mastitis.

ACKNOWLEDGMENTS. We thank Prof. Katsuaki Sugiura (Department of Global Agricultural Sciences, Graduate School of Agricultural and Life Science, The University of Tokyo) for advice in statistical analysis.

\section{REFERENCES}

1. Alvarez, I., Gutiérrez, G., Gammella, M., Martínez, C., Politzki, R., González, C., Caviglia, L., Carignano, H., Fondevila, N., Poli, M. and Trono, K. 2013. Evaluation of total white blood cell count as a marker for proviral load of bovine leukemia virus in dairy cattle from herds with a high seroprevalence of antibodies against bovine leukemia virus. Am. J. Vet. Res. 74: 744-749. [Medline] [CrossRef]

2. Arnold, R. R., Cole, M. F. and McGhee, J. R. 1977. A bactericidal effect for human lactoferrin. Science 197: 263-265. [Medline] [CrossRef]

3. Asfaw, Y., Tsuduku, S., Konishi, M., Murakami, K., Tsuboi, T., Wu, D. and Sentsui, H. 2005. Distribution and superinfection of bovine leukemia virus genotypes in Japan. Arch. Virol. 150: 493-505. [Medline] [CrossRef]

4. Baggiolini, M., De Duve, C., Masson, P. L. and Heremans, J. F. 1970. Association of lactoferrin with specific granules in rabbit heterophil leukocytes. J. Exp. Med. 131: 559-570. [Medline] [CrossRef]

5. Blood, D. C., Radostits, O. M. and Henderson, J. A. 1983. Mastitis. pp. 454-455. In: Veterinary Medicine, 6th ed., Bailliere Tindall, London. 
6. Blowey, R. and Edmondson, P. 2010. Introduction. pp. 1-4. In: Mastitis Control in Dairy Herds, 2nd ed., CAB International, Oxfordshire.

7. Blowey, R. and Edmondson, P. 2010. Teat and udder defenses against mastitis. pp. 20-32. In: Mastitis Control in Dairy Herds, 2nd ed., CAB International, Oxfordshire.

8. Blowey, R. and Edmondson, P. 2010. The mastitis organisms. p. 34. In: Mastitis Control in Dairy Herds, 2nd ed., CAB International, Oxfordshire.

9. Blowey, R. and Edmondson, P. 2010. Somatic cell count, SCC. p. 158. In: Mastitis Control in Dairy Herds, 2nd ed., CAB International, Oxfordshire.

10. Bojarojć-Nosowicz, B. and Kaczmarczyk, E. 2006. Somatic cell count and chemical composition of milk in naturally BLV-infected cows with different phenotypes of blood leukocyte acid phosphatase. Arch. Tierz. Dummerstorf. 49: 17-28.

11. Bramley, A. J., Cullor, J. S., Erskine, R. J., Fox, L. K., Harmon, R. J., Hogan, J. S., Nickerson, S. C., Oliver, S. P., Smith, K. L. and Sordillo, L. M. 2017. Current Concepts of Bovine Mastitis, 5th ed., National Mastitis Council, Madison.

12. Bullen, J. J., Rogers, H. J. and Leigh, L. 1972. Iron-binding proteins in milk and resistance to Escherichia coli infection in infants. BMJ 1: 69-75. [Medline] [CrossRef]

13. Da, Y., Shanks, R. D., Stewart, J. A. and Lewin, H. A. 2015. Milk and fat yields decline in bovine leukemia virus-infected Holstein cattle with persistent lymphocytosis. J. Am. Vet. Med. Assoc. 13: 914-922.

14. Della Libera, A. M., de Souza, F. N., Batista, C. F., Santos, B. P., de Azevedo, L. F., Sanchez, E. M., Diniz, S. A., Silva, M. X., Haddad, J. P. and Blagitz, M. G. 2015. Effects of bovine leukemia virus infection on milk neutrophil function and the milk lymphocyte profile. Vet. Res. (Faisalabad) 46: 2 . [Medline] [CrossRef]

15. Emanuelson, U., Scherling, K. and Pettersson, H. 1992. Relationships between herd bovine leukemia virus infection status and reproduction, disease incidence, and productivity in Swedish dairy herds. Prev. Vet. Med. 12: 121-131. [CrossRef]

16. Frie, M. C. and Coussens, P. M. 2015. Bovine leukemia virus: a major silent threat to proper immune responses in cattle. Vet. Immunol. Immunopathol. 163: 103-114. [Medline] [CrossRef]

17. Hagiwara, S., Kawai, K., Anri, A. and Nagahata, H. 2003. Lactoferrin concentrations in milk from normal and subclinical mastitic cows. J. Vet. Med. Sci. 65: 319-323. [Medline] [CrossRef]

18. Hogan, J. S., González, R. N., Harmon, R. J., Nickerson, S. C., Oliver, S. P., Pankey, J. W. and Smith, K. L. 1999. Laboratory handbook on bovine mastitis. 2nd ed., National Mastitis Council, Inc., Madison, WI., U.S.A.

19. Huang, Y. Q., Morimoto, K., Hosoda, K., Yoshimura, Y. and Isobe, N. 2012. Differential immunolocalization between lingual antimicrobial peptide and lactoferrin in mammary gland of dairy cows. Vet. Immunol. Immunopathol. 145: 499-504. [Medline] [CrossRef]

20. Hurley, W. L. and Rejman, J. J. 1993. Bovine lactoferrin in involuting mammary tissue. Cell Biol. Int. 17: 283-289. [Medline] [CrossRef]

21. Ikebuchi, R., Konnai, S., Shirai, T., Sunden, Y., Murata, S., Onuma, M. and Ohashi, K. 2011. Increase of cells expressing PD-L1 in bovine leukemia virus infection and enhancement of anti-viral immune responses in vitro via PD-L1 blockade. Vet. Res. (Faisalabad) 42: 103. [Medline] [CrossRef]

22. Ikebuchi, R., Konnai, S., Okagawa, T., Yokoyama, K., Nakajima, C., Suzuki, Y., Murata, S. and Ohashi, K. 2013. Blockade of bovine PD-1 increases $\mathrm{T}$ cell function and inhibits bovine leukemia virus expression in B cells in vitro. Vet. Res. (Faisalabad) 44: 59. [Medline] [CrossRef]

23. Isobe, N., Hosoda, K. and Yoshimura, Y. 2009. Immunolocalization of lingual antimicrobial peptide (LAP) in the bovine mammary gland. Anim. Sci. J. 80: 446-450. [Medline] [CrossRef]

24. Isobe, N., Nakamura, J., Nakano, H. and Yoshimura, Y. 2009. Existence of functional lingual antimicrobial peptide in bovine milk. J. Dairy Sci. 92: 2691-2695. [Medline] [CrossRef]

25. Isobe, N., Kubota, H., Yamasaki, A. and Yoshimura, Y. 2011. Lactoperoxidase activity in milk is correlated with somatic cell count in dairy cows. $J$. Dairy Sci. 94: 3868-3874. [Medline] [CrossRef]

26. Juliarena, M. A., Gutierrez, S. E. and Ceriani, C. 2007. Determination of proviral load in bovine leukemia virus-infected cattle with and without lymphocytosis. Am. J. Vet. Res. 68: 1220-1225. [Medline] [CrossRef]

27. Kakinuma, S., Ohtsuka, H., Ohmae, K., Ayabe, K., Kakinuma, M., Konnai, S. and Oikawa, M. 2011. Peripheral blood leukocyte populations in dairy cows infected with bovine leukemia virus. Nippon Juishikai Zasshi 64: 375-380.

28. Kawai, K., Hagiwara, S., Anri, A. and Nagahata, H. 1999. Lactoferrin concentration in milk of bovine clinical mastitis. Vet. Res. Commun. 23: 391-398. [Medline] [CrossRef]

29. Kawai, K., Hayashi, T., Kiku, Y., Chiba, T., Nagahata, H., Higuchi, H., Obayashi, T., Itoh, S., Onda, K., Arai, S., Sato, R. and Oshida, T. 2013. Reliability in somatic cell count measurement of clinical mastitis milk using DeLaval cell counter. Anim. Sci. J. 84: 805-807. [Medline] [CrossRef]

30. Kawai, K., Korematsu, K., Akiyama, K., Okita, M., Yoshimura, Y. and Isobe, N. 2015. Dynamics of lingual antimicrobial peptide, lactoferrin concentrations and lactoperoxidase activity in the milk of cows treated for clinical mastitis. Anim. Sci. J. 86: 153-158. [Medline] [CrossRef]

31. Mekata, H., Sekiguchi, S., Konnai, S., Kirino, Y., Horii, Y. and Norimine, J. 2015. Horizontal transmission and phylogenetic analysis of bovine leukemia virus in two districts of Miyazaki, Japan. J. Vet. Med. Sci. 77: 1115-1120. [Medline] [CrossRef]

32. Murakami, H., Uchiyama, J., Nikaido, S., Sato, R., Sakaguchi, M. and Tsukamoto, K. 2016. Inefficient viral replication of bovine leukemia virus induced by spontaneous deletion mutation in the G4 gene. J. Gen. Virol. 97: 2753-2762. [Medline] [CrossRef]

33. Murakami, K., Kobayashi, S., Konishi, M., Kameyama, K., Yamamoto, T. and Tsutsui, T. 2011. The recent prevalence of bovine leukemia virus (BLV) infection among Japanese cattle. Vet. Microbiol. 148: 84-88. [Medline] [CrossRef]

34. Murphy, K., Travers, P. and Walport, M. 2008. Chapter 8-17. T cell differentiate into several subsets of functionally different effector cells. pp. 349-351 In: Janeway's Immunology, 7th ed., Garland Science, New York.

35. Nekouei, O., VanLeeuwen, J., Stryhn, H., Kelton, D. and Keefe, G. 2016. Lifetime effects of infection with bovine leukemia virus on longevity and milk production of dairy cows. Prev. Vet. Med. 133: 1-9. [Medline] [CrossRef]

36. Ohira, K., Nakahara, A., Konnai, S., Okagawa, T., Nishimori, A., Maekawa, N., Ikebuchi, R., Kohara, J., Murata, S. and Ohashi, K. 2016. Bovine leukemia virus reduces anti-viral cytokine activities and NK cytotoxicity by inducing TGF- $\beta$ secretion from regulatory T cells. Immun. Inflamm. Dis. 4: 52-63. [Medline] [CrossRef]

37. Oliveira, L., Hulland, C. and Ruegg, P. L. 2013. Characterization of clinical mastitis occurring in cows on 50 large dairy herds in Wisconsin. $J$. Dairy Sci. 96: 7538-7549. [Medline] [CrossRef]

38. Panei, C. J., Takeshima, S. N., Omori, T., Nunoya, T., Davis, W. C., Ishizaki, H., Matoba, K. and Aida, Y. 2013. Estimation of bovine leukemia virus (BLV) proviral load harbored by lymphocyte subpopulations in BLV-infected cattle at the subclinical stage of enzootic bovine leucosis using BLV-CoCoMo-qPCR. BMC Vet. Res. 9: 95. [Medline] [CrossRef]

39. Roberson, J. R. 2003. Establishing treatment protocols for clinical mastitis. Vet. Clin. North Am. Food Anim. Pract. 19: 223-234, viii. [Medline] [CrossRef]

40. Rusov, C., Milojevic, Z. and Stojanovic, L. 1994. Occurrence of mastitis and sanitary-hygienic quality of milk of cows infected with enzootic leukosis. Vet. Glas. 48: 303-308. 
41. Sandev, N., Koleva, M., Binev, R. and Ilieva, D. 2004. Influence of enzootic bovine leukosis virus upon the incidence of subclinical mastitis in cows at a different stage of infection. Vet. Arh. 6: 411-416.

42. Sharma, N., Singh, N. K. and Bhadwal, M. S. 2011. Relationship of somatic cell count and mastitis: An overview. Asian-Australas. J. Anim. Sci. 24: 429-438. [CrossRef]

43. Somura, Y., Sugiyama, E., Fujikawa, H. and Murakami, K. 2014. Comparison of the copy numbers of bovine leukemia virus in the lymph nodes of cattle with enzootic bovine leukosis and cattle with latent infection. Arch. Virol. 159: 2693-2697. [Medline] [CrossRef]

44. Souza, F. N., Sanchez, E. M. R., Heinemann, M. B., Gidlund, M. A., Campos, R. L., Blagitz, M. G., Libera, A. M. D. and Cerqueira, M. M. P. 2012. The Innate Immunity in Bovine Mastitis: The Role of Pattern-Recognition Receptors. Am. J. Immunol. 8: 166-678. [CrossRef]

45. Swanson, K., Gorodetsky, S., Good, L., Davis, S., Musgrave, D., Stelwagen, K., Farr, V. and Molenaar, A. 2004. Expression of a beta-defensin mRNA, lingual antimicrobial peptide, in bovine mammary epithelial tissue is induced by mastitis. Infect. Immun. 72: 7311-7314. [Medline] [CrossRef]

46. Thompson-Crispi, K., Atalla, H., Miglior, F. and Mallard, B. A. 2014. Bovine mastitis: frontiers in immunogenetics. Front. Immunol. 5: 493. [Medline] [CrossRef]

47. Vallat, B. and Caporale, V. 2012. Chapter 2.4.11. Enzootic bovine leukosis. pp.721-731. In: Manual of Diagnostic Tests and Vaccines for Terrestrial Animals, 7th ed., World Organisation for Animal Health (OIE), Paris.

48. Zhao, Y., Zhou, M., Gao, Y., Liu, H., Yang, W., Yue, J. and Chen, D. 2015. Shifted T helper cell polarization in a murine Staphylococcus aureus mastitis model. PLoS One 10: e0134797. [Medline] [CrossRef] 